\title{
Influence of Air Temperature in the Emission of Nodes, Ramifications and Flowers in Hybrids of Watermelon (Citrullus lanatus)
}

\author{
Denise Schmidt ${ }^{1}$, Francisco E. Dalla Nora ${ }^{1}$, Daniele C. Fontana ${ }^{2}$, Gizelli M. de Paula ${ }^{1}$, Leonardo A. Thiesen ${ }^{1}$ \\ \& Braulio O. Caron ${ }^{1}$ \\ ${ }^{1}$ Federal Universisty of Santa Maria, Frederico Westphalen Campus, Frederico Westphalen, Rio Grande do Sul, \\ Brazil \\ ${ }^{2}$ Top School in Agriculture Luiz de Queiroz, University of São Paulo, Piracicaba, São Paulo, Brazil \\ Correspondence: Daniele C. Fontana, Top School in Agriculture Luiz de Queiroz, University of São Paulo, \\ Piracicaba, São Paulo, Brazil. Tel: 55-999-469-709. E-mail: daani_fontana@usp.br
}

Received: January 5, 2019

Accepted: February 7, $2019 \quad$ Online Published: April 15, 2019

doi:10.5539/jas.v11n5p131

URL: https://doi.org/10.5539/jas.v11n5p131

The research is financed by FAPERGS for granting the master's scholarship to the second author.

\begin{abstract}
The culture of watermelon develops mainly under conditions of high temperature, being the temperature an element that directly affects the emission of vegetative and reproductive organs. There are no reports of the accumulation of temperature required for emission of branches, nodes and flowers. Thus, this experiment aimed to evaluate the rate of emission of vegetative and reproductive organs for hybrids of watermelon in relation to air temperature, using the hybrids of Manchester and Top Gun watermelons. The experiment was conducted in Federal University of Santa Maria, campus Frederico Westphalen-RS, from September to December 2014. Evaluations were conducted at every two days and it was determined the variables: nodes emission, final number of nodes on the main stem, number of primary and secondary ramifications and number of staminate flowers and open pistillate flowers related to accumulated thermal sum for the emission of such organs, and the ratio between the number of staminate flowers to the pistillate. The hybrids of watermelon present for plastochron of $18.8{ }^{\circ} \mathrm{C}$ node day, final number of nodes of the main ramification of 43 and number of primary and secondary ramifications of eight and 20, respectively. For the emission of staminate and pistillate flowers the hybrids need an accumulation 10.5 and $46.7^{\circ} \mathrm{C}$ day, respectively. The number of staminate and pistillate flowers is 52 and nine, respectively, and the ration between flowers of $6.6: 1$.
\end{abstract}

Keywords: degree-days, thermal sum, accumulated thermal sum

\section{Introduction}

According to FAO (Food and Agriculture Organization), the largest watermelon [Citrullus lanatus (Thunb.) Matsum \& Nakai] production is concentrated in China, accounting for $71 \%$ of the world production, followed by Turkey, Iran and Brazil. In Brazil, the watermelon culture presented an average production of 2 million tons in 2014 (FAOSTAT, 2015) and also has an important social role, being responsible for a large number of jobs, especially in the south, southeast, northeast and midwest regions (Souza et al., 2012).

Of the producing Brazilian states, Rio Grande do Sul (RS) is the largest producer and contributes about $20 \%$ of the national production, it has the largest cultivated area and the largest production in the country, surpassing 19 thousands hectares and about 433 thousand tons, respectively (IBGE, 2014). In RS the ideal climatic conditions occur between the months of September to March, when the average air temperature is about between 18 and $25{ }^{\circ} \mathrm{C}$ (Rezende et al., 2006).

For the species, one of the factors that most influence the cultivation is the air temperature, since it interferes directly in the plant development (Buozo \& Kuchen, 2012). According to Lucas et al. (2012) for the watermelon cultivation the lower base temperature for nodes emission is $7.0^{\circ} \mathrm{C}$ and the superior base temperature is $40{ }^{\circ} \mathrm{C}$, with cardinal temperatures of $10{ }^{\circ} \mathrm{C}, 33{ }^{\circ} \mathrm{C}$ and $42{ }^{\circ} \mathrm{C}$ for the whole cycle (Trentin et al., 2008). Thus, the measurement of air temperature effect is an important tool used to estimate the period of plant development, through the accumulation of thermal units or degree-days above the base temperature estimated for the culture in 
study.

The accumulation of thermal units is validated to predict events like nodes and leaves emission, considering that the emission of these organs maintains a constant until the beginning of fruiting (Baker \& Reddy, 2001). The time interval between the beginning of the formation of leaf primordia, morphological demonstration of apical growth and the development two internodes is called plastochron (Baker \& Reddy, 2001). Thus, plastochron may be the most appropriate variable for understanding the influence of temperature on the physiology of the cultivation, considering the genotype of each species (Streck et al., 2005).

In addition to affecting the nodes emission, temperature directly affects the emission and development of ramifications (Nabinger, 2002). Watermelon presents primary and secondary ramifications (Dias \& Rezende, 2010), and they are originated by cellular differentiation and proliferation of gems, activity caused, mainly, by decreasing dominance of apical meristem (Taiz \& Zeiger, 2013).

Air temperature affects positively or negatively the emission and opening of the flowers, while temperatures above $40{ }^{\circ} \mathrm{C}$ harm the formation of watermelon flowers, both staminate and pistillate, causing abortion of flowers and pollen degradation, thus reducing impregnation of the pistillate flowers (Andrade Junior et al., 2007). For most species of cucurbits, the emission of flowers occurs due to the temperature and the ethylene (Salman-Minkov et al., 2008). The pistillate are the flowers with greater relevance for the crop, being emitted in smaller numbers, influencing the size and shape characteristics of the final fruit (Ulutürk, 2011).

The use of calendar days is a unit that does not reliably express the different periods of the plant development, therefore, for the emission of the first flower buds, the use of STa becomes effective, and, to the Crimson Sweet watermelon cultivar, the first flowers are emitted approximately $415^{\circ} \mathrm{C}$ day (Trentin et al., 2008).

In ideal temperatures, the increasing number of open flowers occurs due to the rapid establishment of the plant, providing an increase in the production of photoassimilate, enabling the accumulation of reserves for the reproductive phase of the plant (Andrade Junior et al., 2007). Thus, the aim of this study was to determine the plastochron, final number of nodes in the main ramification, number of primary and secondary ramifications, flowers emission, number of staminate and pistillate flowers, as well as the ratio between staminate and pistillate flowers for hybrids of watermelon.

\section{Method}

The work was conducted in an experimental area of the Federal University of Santa Maria campus Frederico Westphalen-RS (Universidade Federal de Santa Maria campus Frederico Westphalen-RS), located at 27 $23^{\prime} 48^{\prime \prime}$ S, $53^{\circ} 25^{\prime} 45^{\prime \prime} \mathrm{W}$, with an altitude of $490 \mathrm{~m}$. According to Köppen climate classification, the weather is Cfa, and the predominant soil is the typic alumino-ferric Red Latossol (Embrapa, 1999).

The experimental design used was the randomized complete block using two hybrids of watermelon, with four replications. The experimental unit consisted of three rows of 46.5 meters, composed by the Manchester and Top Gun hybrids. Each block had two lateral rows as a border and the central row as a useful plot. In each replication 10 plants were selected just after the transplantation, which they were labeled, totaling the evaluation in 40 plants of each hybrid. The cultivars were chosen because they present similarities in their water requirement, nutrition, precocity, vigor and other agronomic characteristics.

The seeds were sown in September 2014 in plastic cups of $180 \mathrm{ml}$ capacity, containing commercial substrate at peat basic. After sowing, the containers were placed in a greenhouse with a sprinkling irrigation system.

The preparation of the experimental area was initially constituted by desiccation and subsequent cropping of the area. Subsequently it was held a demarcation of the crop lines and, using a furrow attached to a tractor, the grooves were opened to the transplanting of the seedlings. The fertilization of the culture was held based in the soil analysis of the area, following the recommendation proposed by the Chemistry and Soil Fertility Commission to the states of Rio Grande do Sul and Santa Catarina (Comissão de Química e Fertilidade do Solo) (CQFSRS/SC, 2004). The transplant was carried out on October $8^{\text {th }}, 2014$ manually spacing of $1.5 \mathrm{~m}$ between plants and $3.0 \mathrm{~m}$ between lines. Irrigation management was carried out via drip tap, based on crop evapotranspiration.

The meteorological data like minimum and maximum air temperature were collected from the automatic weather station belonging to the National Institute of Meteorology (Instituto Nacional de Meteorologia) (INMET), located about $330 \mathrm{~m}$ away from the experiment.

The variables used were: number of nodes, final number of nodes on the main stem, number of primary and secondary ramifications, number of staminate flowers and pistillate opened flowers. 
To determine the plastochron of the main stem, emission of primary and secondary ramifications, it was used the thermal sum of the trial period of the crop in the field, until the time that plants do not emit new nodes. To determine the emission of flowers, it was used the thermal sum for the evaluations period of the culture in the field, where the beginning of the reproductive phase has occurred, being held by the counting of the number of male and female opened flowers, held every two days in the morning, until the moment of the emission of flowers stopped, by the presence of growing fruits.

Thermal sum $\left({ }^{\circ} \mathrm{C}\right.$ day) was determined by the equation proposed by Arnold (1960):

$$
S T d=(\text { Tavg }-T b) \cdot 1 \text { day, as Tavg }<T b=0
$$

Where, Tavg was determined by the average of 24 daily air temperature observations and $\mathrm{Tb}$ is the base temperature for the culture, which was determined by Lucas et al. (2012) as being $7{ }^{\circ} \mathrm{C}$. The accumulated thermal sum was calculated by the accumulation of daily degree-days:

$$
S T a=\Sigma S T d
$$

The evaluations were carried out at every two days, counting the number of visible nodes in each evaluation plant. A node was considered visible when the leaf associated to it was $2.0 \mathrm{~cm}$ wide. The emission of primary and secondary ramifications were recorded when they had a $2.0 \mathrm{~cm}$ length of insertion of the leaf axil.

The estimate of the plastochron is the inverse of the angular coefficient of the linear regression between the number of nodes from the main stem and the accumulated thermal sum (Lucas et al., 2012; Streck et al., 2005). The emission of flowers $\left({ }^{\circ} \mathrm{C}\right.$ day node $\left.{ }^{-1}\right)$ was determined to be the inverse of the angular coefficient of the linear regression between the number of flowers and the accumulated thermal sum (STa) from the moment of transplantation to the final location. The calculation for estimating the ratio between staminate and pistillate flowers was made by dividing these two variables.

After the determination of variables, data were subjected to analysis of variance, and their averages were compared by Tukey's test at 5\% significance level. A regression analysis was performed between the accumulated thermal sum and data on the number of main trunk nodes, number of primary and secondary branches and the number of staminate and pistillate flowers.

\section{Results}

The absolute value of the lowest minimum air temperature (Tmin) and the highest maximum temperature (Tmax) was 11 and $35.8^{\circ} \mathrm{C}$, held on October $7^{\text {th }}$ and October $16^{\text {th }}$, respectively (Figure 1).

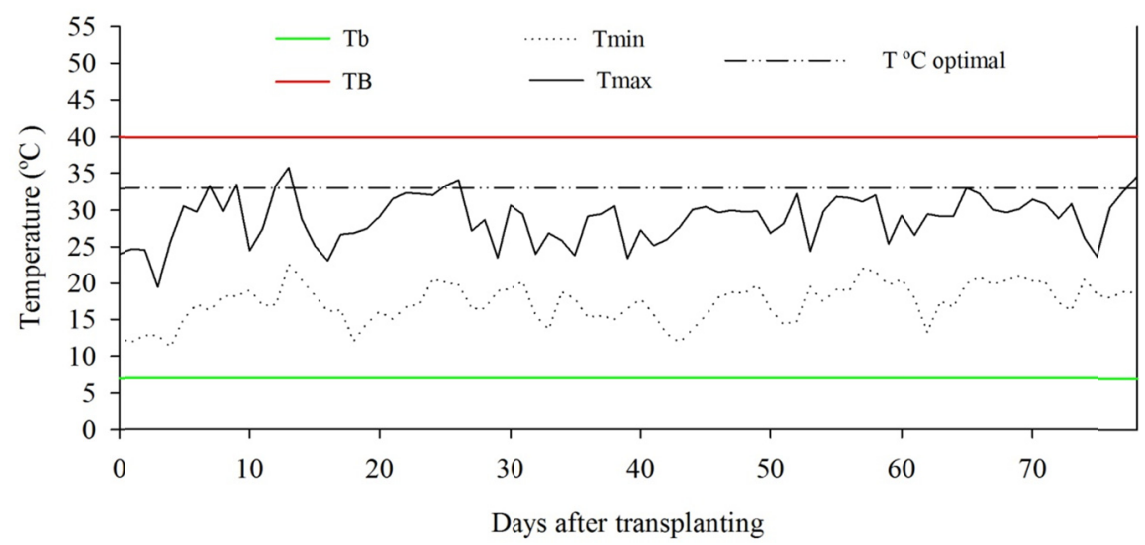

Figure 1. Minimum temperatures (Tmin) and maximum temperatures (Tmax) of the air $\left({ }^{\circ} \mathrm{C}\right)$ collected during the period from 10/03/2014 until 20/12/2014, bounded by the lower basal temperature (Tb), higher basal temperature (TB) and optimal basal temperature $\left(\mathrm{T}^{\circ} \mathrm{C}\right.$ optimal) for the watermelon culture

According to the analysis of variance the variables plastochron, final number of nodes in the main stem and accumulated thermal sum showed no significance for the evaluated hybrids, by the $\mathrm{F}$ test at $5 \%$ probability of error (Figure 2). 


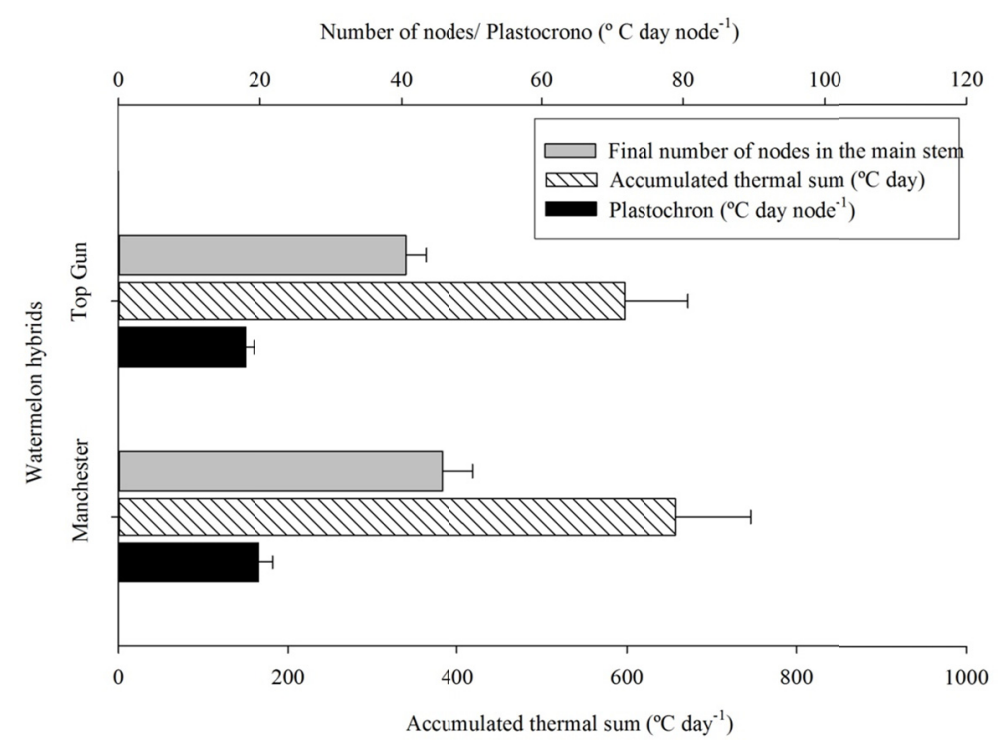

Figure 2. Final number of nodes in the main stem and accumulated thermal sum in the main stem and plastochron of watermelon hybrids

The Manchester hybrid showed an average value for plastochron of $19.8^{\circ} \mathrm{C}$ day node ${ }^{-1}$ and the Top Gun hybrid showed values of $17.9^{\circ} \mathrm{C}$ day node ${ }^{-1}$. Regarding the final number of nodes in the main stem it has been observed that the Manchester hybrid showed 46 nodes and the Top Gun hybrid showed 41 nodes. For the evaluated hybrids, the accumulated thermal summation in the period comprehend between transplanting the seedlings and stopping the emission of nodes in the main stem was 657.6 for the Manchester hybrid and $597.5{ }^{\circ} \mathrm{C}$ day for the Top Gun hybrid (Figure 2).

The variable number of nodes presents a positive linear relation with the accumulated thermal sum $\left({ }^{\circ} \mathrm{C}\right.$ day), demonstrating that the air temperature is a major weather elements responsible for the emission of nodes in the watermelon main stem. Since the water supply of the crop was carried out adequately via dripping. In this regard, the Manchester hybrid showed a value of $15.2^{\circ} \mathrm{C}$ day node $e^{-1}$ and the Top Gun hybrid showed a value of $16.1^{\circ} \mathrm{C}$ day node ${ }^{-1}$, that is, with the values of accumulated degree-days there were emission of a new leaf in the main stem of the hybrids (Figure 3).

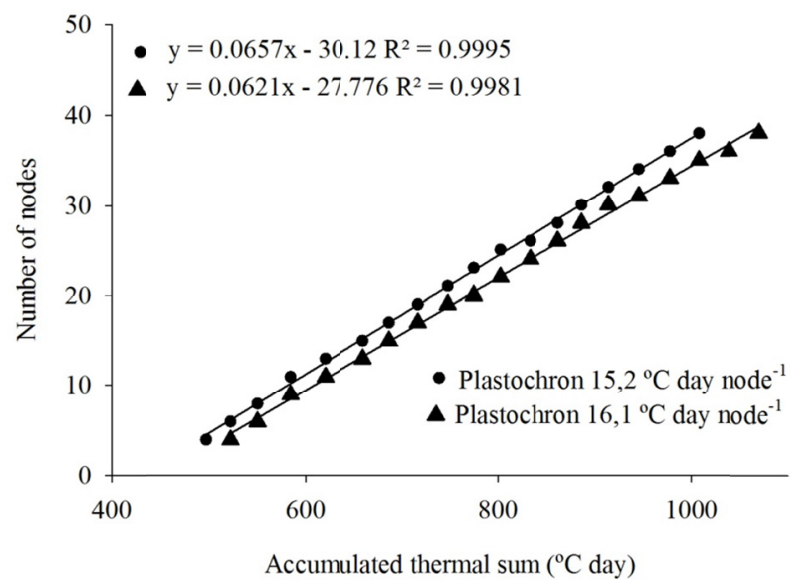

Figure 3. Linear regression for the number of nodes and the accumulated thermal sum of a plant of watermelon hybrids, Manchester and Top Gun, respectively

It was observed an inverse relation between plastochron and the final number of nodes in the main stem of the watermelon hybrids, in which the emission of a new node has occurred with smallest value of plastochron, 
increasing, thus, the emission of nodes (leaves) in the main stem. Due to this fact, the Manchester hybrid showed an average of five nodes more than the Top Gun hybrid. This difference can increase the photosynthetic area in the main stem, providing a significant increase in the production of photoassimilates.

The variables number of primary and secondary ramifications, thermal sum for the emission of primary and secondary ramifications and the number of primary and secondary ramifications, do not show significance, according to the $\mathrm{F}$ test at $5 \%$ probability of error (Figure 4 ).
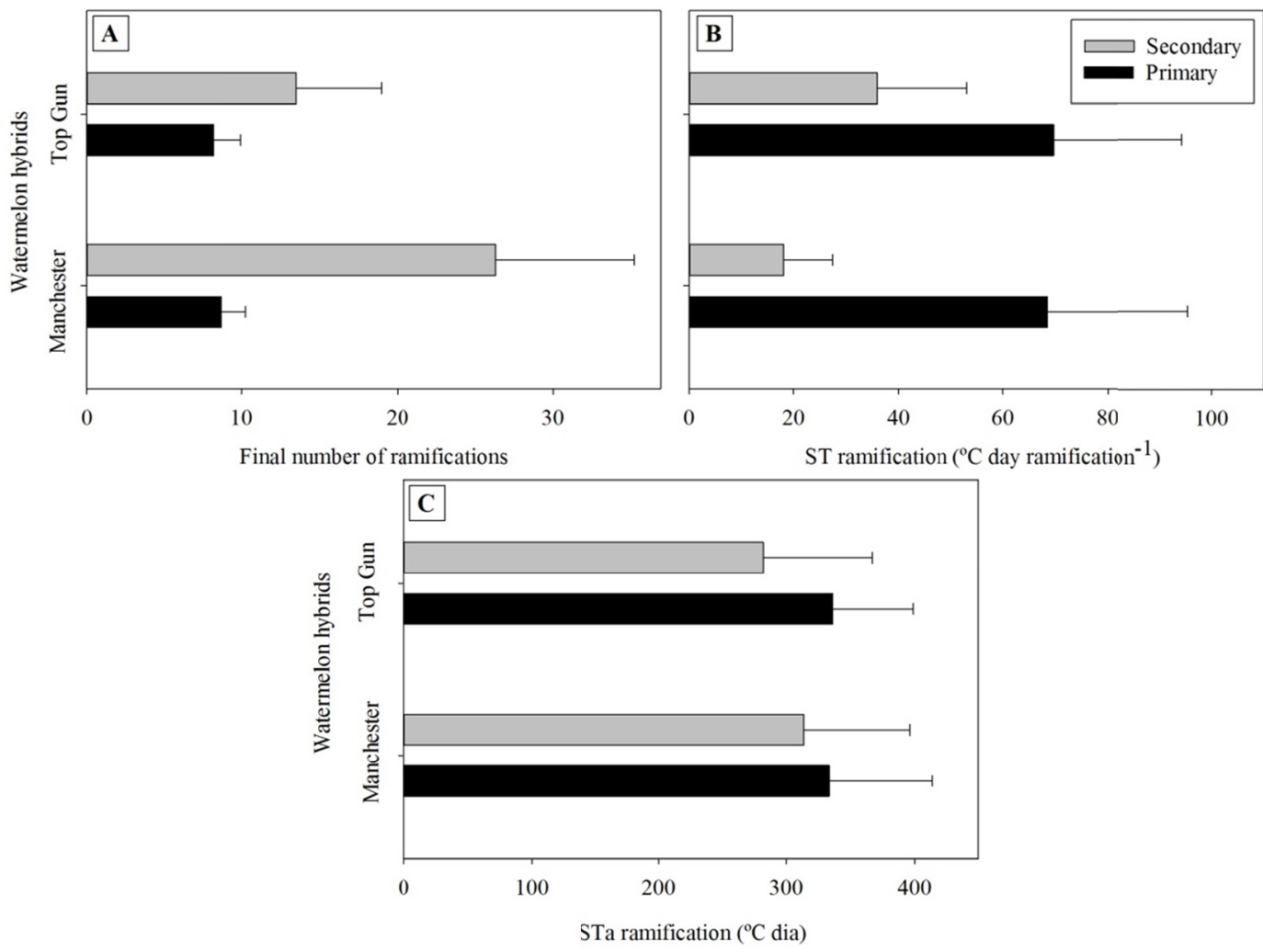

Figure 4. Final number of primary and secondary ramifications (A), thermal sum for the emission of primary and secondary ramifications (B) and accumulated thermal sum (STa) to the emission of primary and secondary ramifications $(\mathrm{C})$ for two watermelon hybrids, Manchester and Top Gun

The accumulated thermal sum for the emission of primary and secondary ramifications had no statistical difference between the hybrids, and it is justified by the similarity of the hybrids cycle, which presented an early cycle. For the emission of primary ramifications, the Manchester and Top Gun hybrids required average values of 68 and $69{ }^{\circ} \mathrm{C}$ day $^{-1}$ ramification, whereas, for the emission of secondary ramifications, the hybrids required average values of 18.1 and $35.9^{\circ} \mathrm{C}$ day $^{-1}$ ramification (Figure 4), respectively.

For the variable final number of primary ramifications, both hybrids of watermelon presented average value of eight primary ramifications per plant. In relation to the final number of secondary ramifications the Manchester hybrid emitted on average 26 secondary ramifications per plant, while the Top Gun hybrid emitted on average 13.5 secondary ramifications per plant (Figure 4). It is believed that it is a genetic trait; that is, linked to intrinsic characteristics of each hybrid, although they do not show statistical differences. In Figure 5 examples of emission of primary and secondary ramifications are shown, depending on the accumulated thermal sum for the evaluated hybrids.

According to the variance analysis performed there were no pair significance to the variables thermal sum of staminate and pistillate flowers, number of staminate and pistillate flowers, as well as the ratio of staminate/pistillate flowers through the $\mathrm{F}$ test at $5 \%$ probability error. 

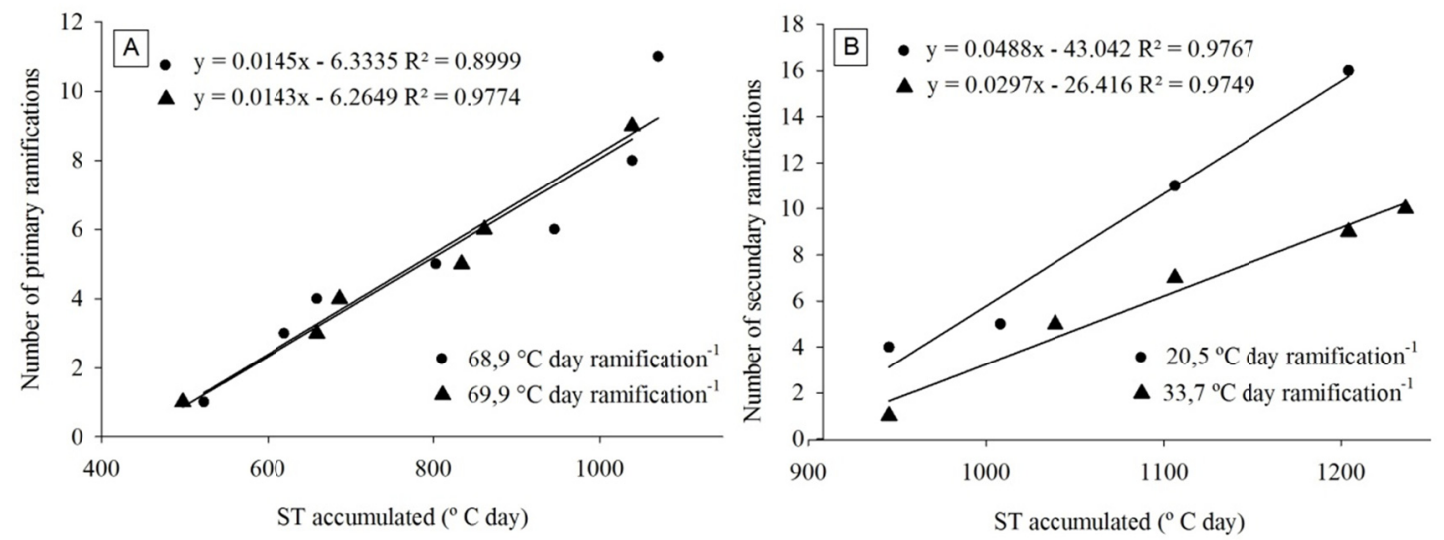

Figure 5. Linear regression between the variables accumulated thermal sum and number of primary (A) and secondary (B) ramifications used for the calculation of the emission of new primary ramifications of two watermelon hybrids, Manchester and Top Gun, respectively

The Manchester hybrid had less need of accumulated degree-days for the emission of a staminate flower, with an average of $9.6^{\circ} \mathrm{C}_{\text {day }}{ }^{-1}$ flower and the Top Gun hybrid showed higher need, presenting an average value of $11.4{ }^{\circ} \mathrm{C}$ day $^{-1}$ flower. The pistillate flowers presented higher need for caloric energy for the occurrence of anthesis of the flower bud, observed average values of $41.6{ }^{\circ} \mathrm{C}$ day flower ${ }^{-1}$ for the Manchester hybrid and $51.9^{\circ} \mathrm{C}$ day flower ${ }^{-1}$ for the Top Gun hybrid (Figure 6A). Thus, the Manchester hybrid showed less need for accumulated degree-days, having faster response to the opening of flowered pistillate buds in relation to the air temperature, when compared to the Top Gun hybrid, even though they do not significantly differ.
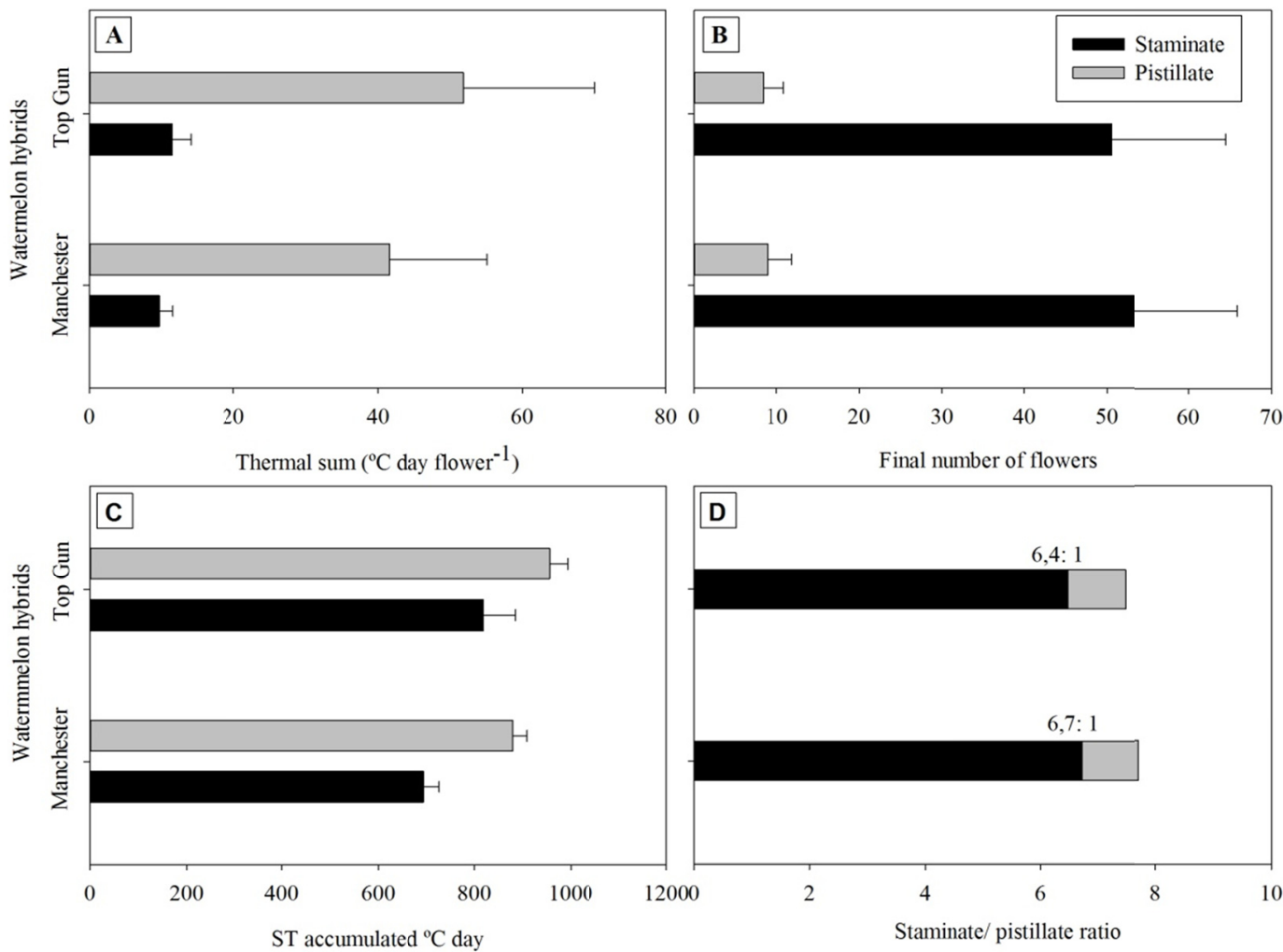

Figure 6. Thermal sum for the emission of staminate and pistillate flowers (A), final number of staminate and pistillate flowers (B), accumulated thermal sum for the emission of staminate and pistillate flowers (C) and the ratio of staminate flowers to pistillate flowers (D) for both two watermelon hybrids, Manchester and Top Gun

To the variable final number of staminate and pistillate flowers the Manchester and Top Gun hybrids showed 
values of 53 and 50 staminate flowers, respectively. In relation to the final number of pistillate flowers, the hybrids did not show distinctive performance, where the Manchester hybrid has presented an average emission of nine pistillate flowers plant ${ }^{-1}$ during the reproductive period and the Top Gun hybrid has presented an average emission of eight flowers plant ${ }^{-1}$ (Figure 6B).

In the reproductive period, during the flowering beginning where $50 \%$ of the plants have opened staminate flowers, the watermelon hybrids demonstrated the need for temperature accumulate with an average accumulated value of $694.5^{\circ} \mathrm{C}$ for Manchester hybrid and $818^{\circ} \mathrm{C}$ accumulated for Top Gun hybrid. In the pistillate flowers, the average needed temperature was $879.3^{\circ} \mathrm{C}$ accumulated for Manchester hybrid and $955.3^{\circ} \mathrm{C}$ accumulated for Top Gun hybrid (Figure 6C). For both watermelon hybrids, opening flowers obeyed their proportionality, with the largest number of staminate flowers over the pistillate flowers in a ratio of 6.7:1 for the Manchester hybrid and 6.4:1 for the Top Gun hybrid (Figure 6D). In Figure 7 two examples of staminate and pistillate flowers emission are shown, respectively. The pistillates flowers, staminate flowers and secondary ramifications are shown in Figure 8 (supplementary figure).
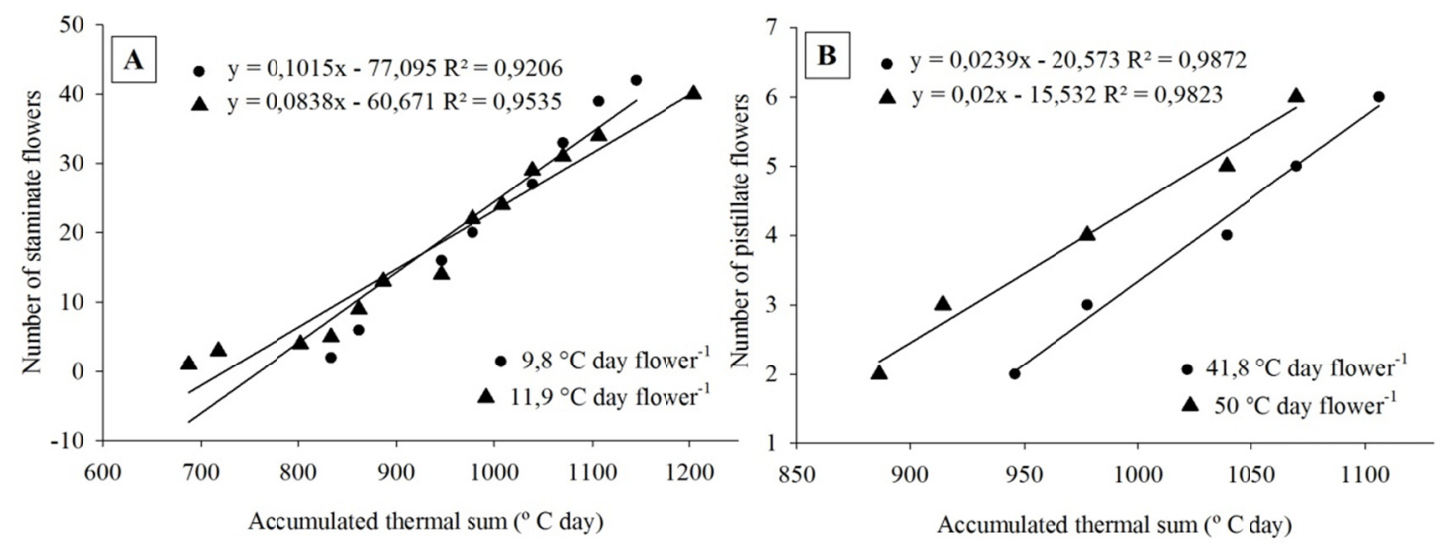

Figure 7. Linear regression between the variables number of staminate (A) and pistillate (B) flowers and accumulated thermal sum used for the emission of staminate and pistillate flowers calculation of a plant for two watermelon hybrids, Manchester and Top Gun, respectively
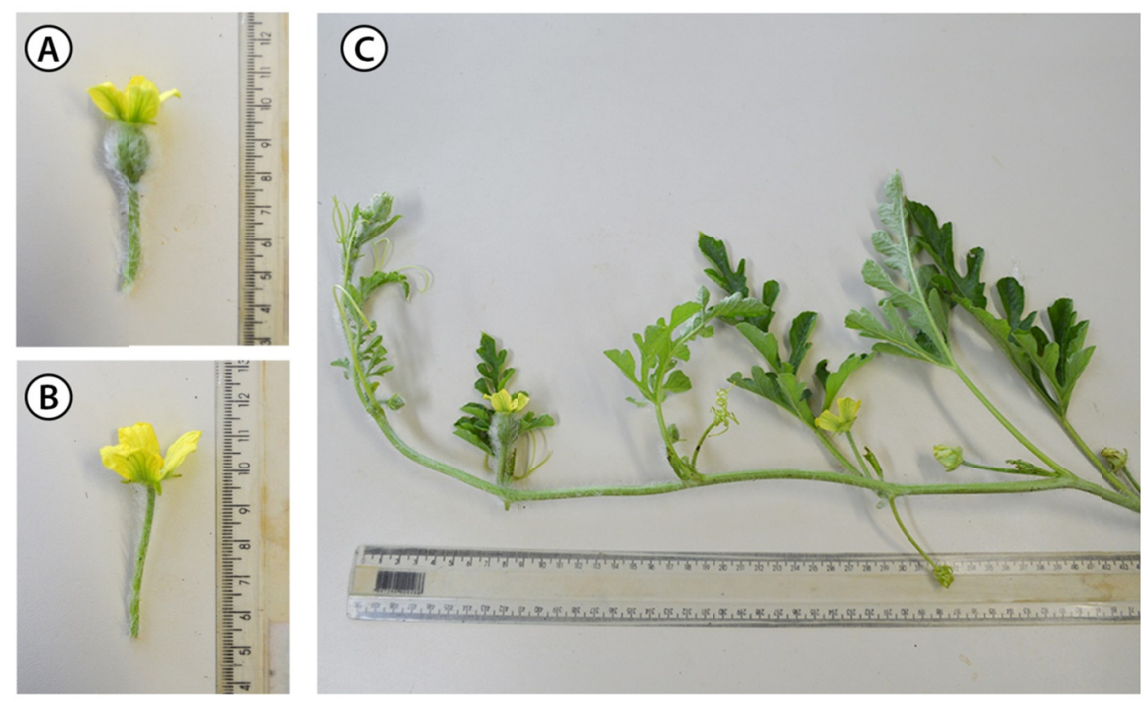

Figure 8. Pistillate flowers (A), Staminate flowers (B), and secondary ramifications (C) of the watermelon hybrids Top Gun and Manchester

\section{Discussion}

Despite the observed variations in the air temperature values, it is observed that the values remain within the tolerated range for culture, which according to Lucas et al. (2012) is between 7.0 and $42{ }^{\circ} \mathrm{C}$. The air temperature 
is directly related the emission speed of vegetative organs of the culture, and it may accelerate or reduce the culture cycle, due to vegetative growth rate, such as emission of new leaves and stem elongation, actions occasioned by cell division in vegetative meristems and vascular tissue in the stem, subsequently paralyzed, occurring the senescence of the plant (Siqueira et al., 2001; Setiyono et al., 2007). It can positively or negatively act on the nodes emission process. Thus, temperatures above or below the optimal physiological cause reductions in plant growth, reducing expansion and cell division of plant tissues (Bahuguna \& Jagadish, 2015). However, thermal stress can affect plant development, however, it does not restrict completely (Caron et al., 2003; Miranda \& Júnior, 2010).

Lucas et al. (2012) evaluating the Crimpson Sweet watermelon cultivar, have found an average value for plastochron of $23.3^{\circ} \mathrm{C}$ day node ${ }^{-1}$, values above those found in this experiment, and Manchester and Top Gun required 19.8 and $17.9^{\circ} \mathrm{C}$, showing that speed emission of a new node on the main stem of the hybrids require less temperature accumulation, justifying their precocity when compared to the cultivars.

In an experiment carried out with Crimson Sweet watermelon cultivar, Lucas et al. (2012) have reported the value of 34.2 nodes, presenting thus, a lower number of nodes in the main stem than what was found in this work Trentin et al. (2008) working with the same cultivar, determined the accumulated thermal sum comprised between the emergence period until the beginning of flowering, from $417.3{ }^{\circ} \mathrm{C}$ day ${ }^{-1}$. However, Lucas et al. (2012) related that the accumulated thermal sum for the same cultivar reached a value of approximately $760{ }^{\circ} \mathrm{C}$ day $^{-1}$ between transplanting and the growth stoppage on the main stem. The same authors observed that the crop was affected when the air temperature exceeded the optimal range of $33^{\circ} \mathrm{C}$, thus reducing its growth.

The difference between this work compared to done by Trentin et al. (2008) with the Crimson Sweet cultivar where the thermal summation value was lower than that of hybrids, being justified by the assessment period in which the authors made the comments before the emission of the first flowers, differing from Lucas's work (2012), where the accumulated thermal sum was counted until the total stoppage period in the emission of nodes in the main stem, as realized in this experiment with hybrids.

The small differences observed between the characteristics of the evaluated hybrids can be justified by the endogenous conditions, related to physiological and morphological factors, such as the speed in cell division process, related to the air temperature (Nabinger, 2002). The same author reports that the air temperature directly affects the number of nodes and leaves, with the temperature rise above 30 , but when it is considered day-degrees or daily thermal sum, leaf appearance speed on the stems becomes relatively constant. Explaining, thus, the least need for degree-days for the Manchester hybrid, causing it to emit higher number of secondary stems and may have to increase the production of photoassimilates, supplying the plant's needs.

The statistical equality between hybrids for all variables can be explained by the similarity of the hybrid cycle, since both are early considered, thus proving the efficiency of the method. In the literature, values for ramification emission for the watermelon culture are presented, such as Silva (2006), where it was done a work with 43 watermelon accessions, observing a range between the accessions, which were recorded the values of 3.7 to 13.7 ramifications of the first order.

The emission of primary ramifications from the main stem is another determining factor for the watermelon culture development, the need for thermal sum was 68 and $69{ }^{\circ} \mathrm{C}$ ramification ${ }^{-1}$, to Manchester and Top Gun, respectively. For the emission of secondary ramification, the Manchester hybrid required approximately $18{ }^{\circ} \mathrm{C}$ and Top Gun $40{ }^{\circ} \mathrm{C}$ day for the emission of one ramification. With this emission, there is an increase in photosynthesizing area, increase in the emission of flowers located in the axillary gems, such in the main stem as in the primary and secondary ramifications (Boyhan et al., 2000).

Although no statistical differences, the Manchester hybrid emitted less primary ramifications and more secondary ramifications when compared to the Top Gun hybrid. This difference may be explained as a way to compensate for the least number of emitted primary ramifications, thereby increasing the photosynthesizing area. Works with reports of thermal sum for the emission of primary and secondary ramifications in watermelon or other Cucurbitaceae were not found.

The difference between the emission of primary and secondary ramification to the evaluated hybrids can be justified by the plant necessity in increasing the production of photoassimilates, and it is not possible to obtain them only with the photosynthetic area formed by the main stem and primary ramification. This difference can be justified due to the plants thermal perception, which can result in changes in the vegetative growth of hybrids (Bahuguna \& Jagadish, 2015).

The anthesis of the first staminate flowers in watermelon culture, according to Costa et al. (2012) takes place 
between 35 and 40 days after emergence. Thus, these values do not express the action of environmental factors acting on the plant growth, making this information be on time in a certain place and cannot be applied to all of watermelon growing regions.

Depending on the final number of staminate flowers, for five cultivars of mini watermelons, Bomfim et al. (2012) had average values of 22.8 flowers plant $^{-1}$ (HA-5161), 40.2 flowers plant $^{-1}$ (Polimore), 43, 9 flowers plant ${ }^{-1}$ (HA-5106), 45.3 flowers plant ${ }^{-1}$ (HA-5158) 49.6 flowers and plant ${ }^{-1}$ (Minipérola). In this same study, average values of pistillate flowers per plant were checked, which ranged from 1.5 flowers (Polimore), 2.2 flowers (HA-5161), 2.7 flowers (Minipérola), 5.32 flowers (HA-5106) and 7.8 flowers (BOMFIM et al., 2012). The values are higher than those verified by Bomfim et al. (2012), both female and male flowers. For this variable, it is believed that is a characteristic linked directly to the plant genotype, having strong influence because it is related to the number of fertilized flowers, which may give rise to a fruit.

Studies of other cultures prove that the air temperature influences the flower anthesis, both complete or unisexual flowers, such as in Zea mays (Lima et al., 2008) and in Gladiolus $\times$ grandiflorus (Streck et al., 2012). The accumulated thermal sum also reported as thermal constant, has been widely used to determine the time necessary to the anthesis of flowers in various vegetables (Volpe et al., 2002). In general, for the emission of pistillate flowers it is necessary higher accumulation of thermal units than for staminate flowers, due to the fact of emitting fewer flowers, and their relationship is of great importance.

In a research done with four watermelon cultivars, the proportion of staminate flowers and pistillate flowers showed average results of 13.3:1 (Super Charleston) 13.4:1 (Elisa), 14.6:1 (Super Crimson) and 24:1 (Congo) (Duarte et al., 2015). Data obtained with the Crimson Sweet cultivar, the proportion of values between the two types of flowers was 5.5:1 (Souza \& Malerbo-Souza, 2005). The values found in this experiment are lower than those observed by Duarte et al. (2015) and higher than Souza and Malerbo-Souza (2005), with 6.7 and 6.4:1 staminate/pistillate to Manchester and Top Gun, respectively. In watermelons, the ratio between the emission of staminate and pistillate flowers on the stem and ramifications is equivalent from four to 15 staminate flowers emitted in the leaf axils to the emission of a pistillate flower, and this feature depends on genetic factors (Salman-Minkov et al., 2008).

In low light conditions, reconciled at mild temperatures, there are higher emission of female flowers, whereas in conditions of days with high temperatures provides greater emission of male flowers (Wehner, 2016). Usually, there are more staminate flowers in relation to pistillate ones, and this relationship tends to be more evident when the temperatures are higher (Nicodemo et al., 2012). This characteristic is also found in other cucurbits such as melons with values of 6.1:1 to 11.3:1 (Crisóstomo et al., 2004), cucumber with values of 3.5:1 to 4.2:1 (Diola et al., 2008) and squash with a value of 2.3:1 (Nicodemo et al., 2007). Ethylene is the main regulator in the transition between male and female phases in the development and in the number of pistillate flowers per plant to different species of the cucurbits family (Silva et al., 2014; Salman-Minkov et al., 2008).

The largest number of staminate flowers in watermelon and also in other cucurbits is extremely important, because these plants are cross-pollination, and due to adhesion characteristics of pollen grains to the stamens, insects are necessary to carry out the collection thereof, for further fertilization of pistillate flowers, it is of fundamental importance this greater proportion between the two types of flowers. It is known that the air temperature directly influences flowering cucurbits, however, there were as yet no data in the literature regarding the number of thermal units required for the emission of primary and secondary ramifications, as well as the emission of pistillate and staminate, making the data obtained in this experiment innovative.

All the objectives established in this work were achieved. The Manchester and Top Gun watermelon hybrids are similar in vegetative and reproductive characteristics. The watermelon hybrids have an average plastochron of $18.8^{\circ} \mathrm{C}$ nodes day, final number of nodes in the main ramification of 43 and number of primary and secondary ramifications of eight and 20, respectively.

For the emission of staminate and pistillate flowers the watermelon hybrids need an average accumulation of 10.5 and $46.7{ }^{\circ} \mathrm{C}$ days, respectively. They present a number of staminate and pistillate flowers of 52 and nine, respectively, and the ratio between flowers of 6.6:1.

\section{References}

Andrade Junior, A. S. S., Rodrigues, B. H. N., Sobrinho, C. A., Bastos, E. A., Melo, F. B., Cardoso, M. J., ... Duarte, R. L. R. (2007). Melancia-Coleção Plantar (2nd ed., p. 85). Embrapa, Brasília.

Arnold, C. Y. (1960). Maximum-minimum temperature as a basis for computing heat units. American Society for Horticulture Science, 76, 682-692. 
Bahuguna R. N., \& Jagadish, K. S. V. (2015). Temperature regulation of plant phenological development. Environmental and Experimental Botany, 111, 83-90. https://doi.org/10.1016/j.envexpbot.2014.10.007

Baker, J. T., \& Reddy, V. R. (2001). Temperature effects on phenological development and yield of muskmelon. Annals of Botany, 605-613. https://doi.org/10.1006/anbo.2001.1381

Bomfim, I. G. A., Bezerra, A. D. M., Nunes, A. C., Aragão, F. A. Z., \& Freitas, B. M. (2012). Emissão, duração e proporção de flores estaminadas e pistiladas em cinco variedades de minimelancia sob cultivo protegido. Horticultura Brasileira, 30, 605-611.

Boyhan, G. E., Granberry, D. M., \& Kelley, W. T. (2000). Commercial Watermelon Production (Bulletin 996). Cooperative Extension Service, The University of Georgia College of Agricultural and Environmental Sciences. Retrieved from http://www.agmrc.org/media/cms/B996_B3D54FD90A36C.pdf

Buozo, C. A., \& Küchen, M. G. (2012). Effect of temperature on melon development rate. Agronomy Research, 10, 283-294.

Caron, B. O., Medeiros, S. L. P., Manfron, P. A., Schmidt, D., Pommer, S. F., \& Bianchi, C. (2003). Influência da temperatura do ar e radiação solar no acúmulo de fitomassa da alface. Revista Brasileira de Agrometeorologia, 11, 275-283.

Costa, J. A., Dias, R. C. S., Santos, S. S., Andrade, K. M. N. S., \& Lubarino, P. C. C. (2012). Emergência e florescimento em acessos de melancia. Jornada de Iniciação Científica da Embrapa Semiárido, 7. Jornada de Iniciação Científica da FACEPE/UNIVASF, 1, 2012, Petrolina. Anais... Petrolina: Embrapa Semiárido.

CQFSRS/SC (Comissão de Química e Fertilidade do Solo). (2004). Manual de adubação e calagem para os estados do Rio Grande do Sul e Santa Catarina (10th ed.). Porto Alegre, Sociedade Brasileira de Ciência do Solo/Núcleo Regional Sul.

Crisóstomo, J. R., Falcão, L. F., Aragão, F. A. Z., Freitas, J. G., Silva, J. F., Santos, F. H. C., \& Jalmi, G. (2004). Biologia Floral do Meloeiro no Ceará: Emissão, Duração e Relação Flores Masculinas/Hermafroditas. Horticultura Brasileira, 22(Suppl. 2).

Dias, R. C. S., \& Rezende, G. M. (2010). Sistema de produção de melancia. Retrieved from http://sistemasde producao.cnptia.embrapa.br/FontesHTML/Melancia/SistemaProducaoMelancia/colheita.htm

Diola, V., Orth, A. I., \& Guerra, M. P. (2008). Reproductive biology in monoecious and gynoecious cucumber cultivars as a result of IBA application. Horticultura Brasileira, 26, 030-034. https://doi.org/10.1590/ S0102-05362008000100006

Duarte, P. M., Siqueira, K. M. M., Silva, N. C., Silva, G. B. S., \& Goms, I. L. S. (2015). Floração e morfologia floral de variedades de melancieira em Juazeiro-BA. Revista Verde de Agroecologia e Desenvolvimento Sustentável, 10, 72-76. https://doi.org/10.18378/rvads.v10i3.3431

Embrapa. (1999). Centro Nacional de Pesquisa de Solos (p. 412). Sistema Brasileiro de Classificação de Solos, Rio de Janeiro.

FAOSTAT. (2015). Food and Agriculture Organization of the United Nations, Statistics Division. Retrieved from http://faostat3.fao.org/download/Q/QC/E.FAOSTAT

IBGE (Instituto Brasileiro de Geografia e Estatística). (2015). Retrieved from http://www.sidra.ibge.gov.br/bda/ tabela/listabl.asp?c $=1612 \& \mathrm{z}=\mathrm{p} \& \mathrm{o}=18$

Lima, J. L., Souza, J. C., Machado, J. C., \& Ramalho, M. A. P. (2008). Controle genético da exigência térmica para o início do florescimento em milho. Bragantia, 67, 127-131. https://doi.org/10.1590/S0006 $-87052008000100015$

Lucas, D. P., Streck, N. A., Bortoluzzi, M. P., Trentin, R., \& Maldaner, I. C. (2012). Temperatura base para emissão de nós e plastocrono de plantas de melancia. Revista de Ciências Agronômicas, 43, 288-292.

Miranda, M. N., \& Júnior, J. H. C. (2010). Soma térmica para o subperíodo semeadura-maturação de feijão cv. carioca em Colorado do Oeste, Rondônia. Pesquisa Agropecuária Tropical, 40, 180-185. https://doi.org/ 10.5216/pat.v40i2.6790

Nabinger, C. (2002). Modelo Morfogênico da produção potencial de flores em alfafa (Medicago sativa L.). (218f., Tese, Universidade Federal do Rio Grande do Sul. Porto Alegre, RS).

Nicodemo, D., Couto, R. H. N., Malheiros, E. B., \& Jong, D. (2007). Biologia floral em moranga (Cucurbita maxima Duch. var. Exposição"). Acta Scientiarum. Agronomy, 29, 611-616. https://doi.org/10.4025/ 
actasciagron.v29i5.735

Rezende, G. M., Costa, N. D., \& Dias, R. C. S. (2006). Cultura da Melancia. Sistema de Produção Embrapa Semi-Árido. Retrieved from http://www.cpatsa.embrapa. br

Salman-Minkov, A., Levi, A., Wolf, S. \& Trebitsh, T. (2008). Acc synthase genes are polymorphic in watermelon and differentially expressed in flowers and in response to auxin and gibberellin. Plant Cell Physiol., 49, 740-750. https://doi.org/10.1093/pcp/pcn045

Setiyono, T. D., Weiss, A., Specht, J., Bastidas, A. M., Cassman, K. G., \& Dobermann, A. (2007). Understanding and modeling the effect of temperature and daylength on soybean phenology under high-yield conditions. Field Crops Research, 100, 257-271. https://doi.org/10.1016/j.fcr.2006.07.011

Silva, L. M., Queiroz, M.A., Ferreira, M. A. J. F., \& Buso, G. S. C. (2006). Caracterização morfológica e molecular de acessos de melancia. Horticultura Brasileira, 24, 405-409. https://doi.org/10.1590/S010205362006000400002

Siqueira, O. J. W., Steinmetz, S., \& Salles, L. A. B. (2001). Efeitos potenciais das mudanças climáticas na agricultura brasileira e estratégias adaptativas para algumas culturas. In M. A. Lima, O. M. R. Cabral, \& J. D. G. Miguez (Eds.), Mudanças climáticas globais e a agropecuária brasileira (pp. 33-63). Jaguariúna: EMBRAPA.

Souza, F. F., Dias, R. C. S., \& Queiroz, M. A. (2012). Avaliação de descritores morfológicos de folha e flor em acessos de melancia (pp. 1-4). II Congresso Brasileiro de Recursos Genéticos.

Souza, F. F., \& Malerbo-Souza, D. T. (2005). Entomofauna visitante e produção de frutos em melancia (Citrullus lanatus Thunb.)-Cucurbitaceae. Acta Scientiarum, 21, 579-583.

Streck, N. A., Paula, G. M. de, Camera, C., Menezes, N. L. \& de Lago, I. (2005). Estimativa do plastocrono em meloeiro (Cucumis melo L.) cultivado em estufa plástica em diferentes épocas do ano. Ciência Rural, 35, 1275-1280. https://doi.org/10.1590/S0103-84782005000600008

Streck, N. A., Paula, G. M. de, Camera, C., Menezes, N. L., \& Lago, I. (2008). Estimativa do plastocrono em cultivares de soja. Bragantia, 67, 67-73. https://doi.org/10.1590/S0006-87052008000100008

Streck, N. A., Bellé, R. A., Backes, F. A. A. L., Gabriel, L. F., Uhlmann, L. O., \& Becker, C. C. (2012). Desenvolvimento vegetativo e reprodutivo em gladíolo. Ciência Rural, 42, 1968-1974. https://doi.org/ 10.1590/S0103-84782012001100010

Silva, D. R. M., Cunha, C. S. M., \& Felipe, E. A. (2014). Aspectos vegetativos e reprodutivos para a cultura da melancia sob diferentes coberturas de solo e níveis de irrigação em Teresina-PI. Agropecuária Científica no Semiárido, 10, 96-103.

Taiz, L., \& Zeiger, E. (2013). Fisiologia vegetal (5th ed., p. 918). Porto Alegre: Artmed.

Trentin, R., Schreiber, F., Streck, N. A., \& Buriol, G. A. (2008). Soma térmica de subperíodos do desenvolvimento da planta de melancia. Ciência Rural, 38, 2464-2470. https://doi.org/10.1590/S010384782008000900008

Ulutürk, Z. I., Frary, A., \& Doganlar, S. (2011). Determination of Genetic Diversity in Watermelon (Citrullus lanatus (Thunb.) Matsum \& Nakai) Germplasm. Australian Journal of Crop Science, 13, 1832-1836.

Volpe, C. A., Schoffel, E., \& Barbosa, J. C. (2002). Influência da soma térmica e da chuva durante o desenvolvimento de laranjas 'Valência' e 'Natal' na relação entre sólidos solúveis e acidez e no índice tecnológico do suco. Revista Brasileira de Fruticultura, 24, 436-441. https://doi.org/10.1590/S010029452002000200031

Wehner, T. C. (2016). Watermelon (pp. 368-405). Retrieved from http://cuke.hort.ncsu.edu/cucurbit/wehner/ articles/book16.pdf

\section{Copyrights}

Copyright for this article is retained by the author(s), with first publication rights granted to the journal.

This is an open-access article distributed under the terms and conditions of the Creative Commons Attribution license (http://creativecommons.org/licenses/by/4.0/). 